\title{
EFEKTIFITAS KONSELING KELOMPOK UNTUK MENINGKATKAN \\ MOTIVASI BELAJAR SISWA SMK YANG MENGALAMI \\ KETIDAKSESUAIAN PILIHAN JURUSAN
}

\author{
Umdatul Khoirot \\ Fakultas Psikologi \\ Universitas Islam Negeri (UIN) Maulana Malik Ibrahim Malang \\ Umdatul.khoirot@gmail.com
}

\begin{abstract}
The purpose of this study was to test the effectiveness of group counseling to increase the motivation of vocational students who experienced a mismatch in the choice of majors. The research subjects were 8 students of class $X$ who experienced a discrepancy in their choice of majors. The research method is a quasi-experimental method with the One-group pretest-posttest design technique. Analysis of the data used is the paired sample t-test to see differences in the learning motivation of SMK students who experience discrepancies in the choice of majors before and after being given treatment. The results showed that there was an increase in students' motivation scores after being given treatment, which means that group counseling was effective in increasing the learning motivation of SMK students who experienced a mismatch in the choice of majors.
\end{abstract}

Keywords: learning motivation, group counseling, incompatibility of choice with majors

\begin{abstract}
Abstrak
Tujuan dari penelitian ini adalah menguji efektifitas konseling kelompok untuk meningkatkan motivasi siswa SMK yang mengalami ketidaksesuaiana pilihan jurusan. Subjek penelitian adalah 8 siswa kelas $\mathrm{X}$ yang mengalami ketidaksesuaian pilihan dengan bidang jurusan. Metode penelitian yang dilakukan adalan kuasi eksperimen dengan Teknik One-group pretest-posttest design. Analisis data yang digunakan adalah dengan paired sample t-test untuk melihat perbedaan motivasi belajar siswa SMK yang mengalami ketidaksesuaian pilihan jurusan sebelum dan sesudah diberikan perlakuan. Hasil penelitian menunjukkan bahwa ada peningkatan skor motivasi siswa setelah diberikan perlakukan, yang artinya konseling kelompok efektif untuk meningkatkan motivasi belajar siswa SMK yang mengalami ketidaksesuaian pilihan jurusan.
\end{abstract}

Kata kunci: motivasi belajar, konseling kelompok, ketidaksesuaian pilihan dengan bidang jurusan 


\section{PENDAHULUAN}

Dalam kehidupan sekolah, siswa tidak akan lepas dari belajar, belajar merupakan sebuah proses untuk mendapatkan pengalaman ataupun hal-hal baru yang dihasilkan dari proses interaksi yang dilakukan oleh individu dengan lingkungan ${ }^{1}$. Dari proses belajar inilah perubahan-perubahan akan muncul dalam diri individu karena adanya interaksi yang dilakukan baik itu dengan teman, keluarga maupun orang lain yang ada disekitarnya. Melalui belajar inilah individu mengembangkan potensi-potensi yang dimilikinya dengan disertai dorongan atau motivasi yang dimunculkan oleh individu tersebut. Selain motivasi, belajar juga perlu dibarengi dengan adanya minat. Berdasarkan Kamus Besar Bahasa Indonesia ${ }^{2}$ minat di definisikan sebagai keinginan hati yang tinggi terhadap sesuatu hal. Proses belajar siswa sangat dipengaruhi oleh minat belajar yang dimiliki. Melalui minat ini, ketertarikan siswa untuk mempelajari suatu hal dapat timbul dari dalam diri mereka, sehingga dapat belajar dengan baik. banyak factor yang dapat memberikan pengaruh terhadap belajar siswa. Azwar ${ }^{3}$ mengungkapkan bahwa minat dam motivasi menjadi salah satu faktor yang memberikan pengaruh. Ungkapan tersebut diperkuat pula dengan penelitian yang dilakukan oleh Heriyati ${ }^{4}$ dan Ricardo \& Meilani ${ }^{5}$; Sari, Safitri \& Sasmita ${ }^{6}$; Putri ${ }^{7}$; Rahayu ${ }^{8}$ yang Menunjukkan bahwa minat dan motivasi berpengaruh terhadap

\footnotetext{
${ }^{1}$ Slameto, Belajar Dan Faktor-Faktor Yang Mempengaruhinya (Jakarta: Rineka Cipta, 2003).

2 Kemendikbud RI, Kamus Besar Bahasa Indonesia (Jakarta, 2021).

${ }^{3}$ S. Azwar, Pengantar Psikologi Intelegensi, 10th ed. (Yogyakarta: Pustaka Pelajar, 2010).

${ }^{4}$ Heriyati Heriyati, "Pengaruh Minat Dan Motivasi Belajar Terhadap Prestasi Belajar Matematika," Formatif: Jurnal Ilmiah Pendidikan MIPA 7, no. 1 (2017): 22-32, https://doi.org/10.30998/formatif.v7i1.1383. ${ }^{5}$ Ricardo Ricardo and Rini Intansari Meilani, "Impak Minat Dan Motivasi Belajar Terhadap Hasil Belajar Siswa," Jurnal Pendidikan Manajemen Perkantoran 2, no. 2 (2017): 79, https://doi.org/10.17509/jpm.v2i2.8108.

${ }^{6}$ Ira Nofita Sari, Dwi Fajar Saputri, and Sasmita Sasmita, "Pengaruh Minat Dan Motivasi Belajar Terhadap Prestasi Belajar Fisika Pada Siswa Kelas XI IPA SMA Negeri 1 Galing Kabupaten Sambas," Jurnal Edukasi Matematika Dan Sains 4, no. 2 (2017): 108, https://doi.org/10.25273/jems.v4i2.691.

${ }^{7}$ G. Putri, D. T. N. ; Isnani, "Pengaruh Minat Dan Motivasi Terhadap Hasil Belajar Pada Mata Pelajaran Pengantar Administrasi Perkantoran," Jurnal Pendidikan Bisnis Dan Manajemen 1, no. 2 (2015): 118-24.

${ }^{8}$ MARGINING RAHAYU, "Pengaruh Minat Dan Motivasi Belajar Terhadap Hasil Belajar Siswa Di Smk Ketintang Surabaya," Jurnal Pendidikan Akuntansi (JPAK) 1, no. 3 (2013): 1-17.
} 
hasil belajar siswa. Djalali (dalam Kurniawan \& Santoso ${ }^{9}$ ) mengungkapkan bahwa minat yang secara sadar muncul dari dalam diri siswa terhadap suatu pelajaran, memungkinkan siswa untuk menjaga pikirannya, sehingga dapat menguasai mata pelajaran tersebut.

Sukada, Sadia \& Yudana ${ }^{10}$ mengungkapkan bahwa terdapat hubungan yang positif antara minat dan motivasi berprestasi siswa dengan kecerdasan logisnya matematika terhadap hasil belajar matematika siswa. Menurut Alsa \& Haditono (dalam Aulia ${ }^{11}$ ) prestasi tinggi yang dapat dicapai oleh siswa dapat memberikan pengaruh positif terhadap psikologisnya, diantaranya adalah pada kepercayaan diri, munculnya dorongan untuk berprestasi, dan aspirasi yang tinggi dari siswa tersebut. Djamarah ${ }^{12}$ mengungkapkan bahwa alat motivasi yang paling penting adalah minat, sehingga dengan adanya minat tersebut dapat membangkitkan dorongan dan kemauan belajar siswa, dengan adanya minat juga proses belajar siswa akan menjadi lancar. Minat ini berkaitan dengan perasaan. Lembih lanjut dalam hasil penelitian nya, Djamarah ${ }^{13}$ mengungkapkan bahwa individu yang memiliki minat tinggi pada suatu hal, dia cenderung memberikan perhatian penuh terhadap hal tersebut, dijelaskan pula dalam hasil penelitian yang dilakukan oleh Syafitri ${ }^{14}$ bahwa siswa yang pandangan siswa mengenai sekolah yang negatif (tidak memiliki manfaat menurutnya) baik itu secara langsung maupun tidak, akan menurunkan motivasi siswa dalam belajar di sekolah.

Sedangkan motivasi merupakan sebuah keadaan dalam diri seorang individu yang dapat memicu munculnya ketekunan, dorongan, energi, dan arah perilaku (Ferguson dalam Cox \& Klinger ${ }^{15}$ ). Definisi ini mencakup dampak dari suatu dorongan seperti rasa lapar,

\footnotetext{
${ }^{9}$ Dwi Lathif Kurniawan and Djoko Santoso, "Pengaruh Lingkungan Belajar, Minat Belajar Dan Motivasi Belajar Terhadap Prestasi Belajar Siswa Pada Mata Pelajaran Tik Kelas x Sma n 1 Kota Mungkid, Magelang," Universitas Negeri Yogyakarta: Thesis, 2013.

${ }^{10}$ I K Sukada, W Sadia, and M Yudana, "Dan Kecerdasan Logis Matematika Terhadap Hasil Belajar Matematika Siswa Sma Negeri 1 Kintamani" 4 (2013).

${ }^{11}$ Aulia, "Efektivitas Konseling Kelompok Untuk Meningkatkan Motivasi Belajar Siswa Kelas XI IPS Yang Mengalami Ketidaksesuaian Pilihan Dengan Bidang Jurusan" (Universitas Gajah Mada, 2006).

${ }^{12}$ S. B. Djamarah, Psikologi Belajar (Jakarta: Rineka Cipta, 2002).

${ }^{13}$ Djamarah.

${ }^{14}$ A. Syafitri, "Gambaran Aspek-Aspek Yang Mempengaruhi Prestasi Belajar Pada Siswa SMUN 106 Jakarta Yang Berprestasi Akademik Rendah," Jurnal Psikodinamik 2 (2004): 39-57.

${ }^{15}$ E. Cox W. M. ; Klinger, Handbook of Motivational Counseling Concepts, Approaches, and Assessment (England: John Wiley \& Sons, Ltd., 2004).
} 
kondisi emosional seperti kecemasan dan kemarahan, dan banyak variasi lain dari keadaan batiniah. Kedua definisi ini mencantumkan kualitas utama dari perilaku, bahwa motivasi di definisikan untuk mempengaruhi: inisiatifnya, ketekunan, semangat dan arah $\left(\right.$ Schunk $\left.{ }^{16}\right)$. Ada hubungan antara prestasi siswa dengan motivasi yang dimiliki. Motivasi belajar yang lemah dapat menyebabkan prestasi belajar siswa juga lemah.

Berdasarkan hasil assesmen yang dilakukan di SMK "X" Yogyakarta, diketahui bahwa banyak siswa mengalami ketidaksesuaian jurusan yang diinginkan dengan jurusan yang saat ini dipilih. Ketidaksesuaian minat jurusan yang dialami ini menjadi faktor yang menyebabkan mereka menjadi kurang memiliki dorongan atau motivasi untuk belajar. Manifestasi perilaku yang dimunculkan adalah kurangnya keikutsertaan siswa dalam proses pembelajaran dikelas, membolos, keluar kelas, ataupun tidur dan tidak memperhatikan penjelasan guru. Hal ini mengakibatkan pada penurunan prestasi belajar siswa, banyak siswa yang mengungkapkan harus mengulang beberapa mata pelajaran dikarenakan nilai yang diperoleh berada dibawah standar minimal kelulusan. Melihat fenomena ini, perlu adanya penanganan untuk meningkatkan motivasi belajar siswa meskipun mereka salah dalam memilih jurusan, sehingga siswa dapat menikmati proses belajarnya dan dapat mencapai prestasi yang optimal.

Berdasarkan paparan diatas, penelitian ini dilakukan untuk menguji efektifitas konseling kelompok untuk meningkatkan motivasi belajar siswa SMK yang mengalami ketidaksesuaian pilihan jurusan.

\section{METODE PENELITIAN}

Metode penelitian yang digunakan dalam penelitian ini adalah kuantitatif dengan desain kuasi eksperimen. Rancangan eksperimen dilakukan dengan membandingkan hasil pre test dan post test dalam satu kelompok yang diberikan perlakuan (One-group pretestposttest design) (Shadish, Cook \& Campbel $^{17}$ ).

\footnotetext{
${ }^{16}$ D.H. Schunk, Learning Theories: An Educational Perspective, 6th ed. (Boston: Allyn \& Bacon, 2012).

${ }^{17}$ D. T. Shadish, W. R., Cook, T. D., \& Campbell, Experimental and Quasi-Experimental Designs for Generalized Causal Inference (Boston: Houghton Mifflin Co., 2002).
} 
Partisipan penelitian ini adalah delapan siswa kelas kelas X SMK yang mengalami ketidaksesuaian minat jurusan dengan skor motivasi sedang, yang dipilih melalui Teknik purposive sampling.

Alat pengumpulan data dalam penelitian ini menggunakan skala motivasi belajar dan angket minat jurusan. Angket ketidaksesuaian minat jurusan diadaptasi dari Aulia ${ }^{18}$, untuk melihat kesesuaian minat jurusan yang diambil saat ini dengan sebelum mendaftar disekolah. Angket ini berisi pertanyaan terbuka sejumlah 7 pertanyaan. Sedangkan skala motivasi belajar yang digunakan juga diadaptasi dari skala yang disusun oleh Aulia ${ }^{19}$, yang terdiri dari 39 aitem dengan skor reliabilitas 0,92 .

Paired sample t-test digunakan untuk melakukan analisis data penelitian dengan bantuan IMB Statistic SPSS 26, untuk menguji skor motivasi yang diperoleh siswa dalam pre-test dan post-test.

\section{HASIL DAN PEMBAHASAN}

Tujuan penelitian ini adalah menguji efektivitas konseling kelompok untuk meningkatkan motivasi belajar siswa SMK yang mengalami ketidaksesuaian pilihan jurusan. Peningkatan motivasi belajar siswa dilakukan melalui pengenalan dan pengembangan pribadi serta potensi yang dimiliki. Konseling kelompok ini merupakan upaya untuk membantu siswa dalam suasana interaksi dengan beberapa siswa lain sebagai bentuk pencegahan maupun penyembuhan $\left(\mathrm{Aulia}^{20}\right)$.

Konseling kelompok dilakukan dalam 6 sesi. Sesi pertama merupakan sesi perkenalan, dalam sesi ini siswa diajak untuk mengenali diri sendiri dengan mencari hal positif maupun negatif yang ada dalam dirinya. Selain itu pengenalan diri juga diperoleh dari informasi yang diberikan teman dengan cara menanyakan langsung kepada temantemannya. Pada sesi kedua, siswa diminta untuk menemukan masalah belajar yang dialami dan menetapkan target perubahan yang ingin dicapai. Sesi 3 merupakan lanjutan dari sesi kedua, pada sesi ini siswa diingatkan kembali mengenai permasalahan belajarnya, kemudian mereka diberi kesempatan untuk memberikan umpan balik, berbagi

\footnotetext{
${ }^{18}$ Aulia, "Efektivitas Konseling Kelompok Untuk Meningkatkan Motivasi Belajar Siswa Kelas XI IPS Yang Mengalami Ketidaksesuaian Pilihan Dengan Bidang Jurusan."

19 Aulia.

${ }^{20}$ Aulia.
} 
pengalaman, pikiran dan perasaan kepada teman dalamkelompok konseling ini. Pada Sesi 4, dibuka dengan permainan sarang korek api. Mereka secara berpasangan diminta untuk menyusun batang korek api diatas botol sampai membentuk sebuah sarang, permainan ini bertujuan untuk melatih siswa untuk berani mengambil keputusan dan menerima semua akibat yang didapatkan. Setelah itu, peneliti membuka dengan memberikan penjelasan mengenai pentingnya pengambilan keputusan dalam kehidupan. Siswa dibagai menjadi empat kelompok dimana masing-masing kelompok terdiri dari 2 siswa. Kemudian diminta untuk mengingat dan berfikir mengenai keputusan-keputusan yang dilakukan dari bangun tidur sampai dengan siswa berada dalam konseling kelompok ini.

Sesi 5 adalah lanjutan dari sesi 4, setelah mereka belajar bagaimana cara mengambil keputusan, mereka diajak untuk mengevaluasi prestasi dan hambatan yang dialami selama belajar, dan belajar menetapkan tujuan dengan mempertimbangkan aspek waktu yang dibutuhkan, spesifikasi tujuan tersebut, realitis, dan rincian secara kuantitatifnya. Disini mereka belajar untuk menganalisis kekuatan dan kelemahan yang dimiliki serta ancaman kemungkinan dihadapi dan kesempatan yang masih bisa dilakukan. Sesi 6 adalah sesi penutup dan evaluasi, pada sesi ini, siswa diminta untuk mengisi lembar penilaian dan berdiskusi mengenai pengalaman yang didapatkan selama mengikuti konseling kelompok, sebagian besar siswa mengungkapkan sesi konseling kelompok sangat bermanfaat dan membantu dalam kehidupan sehari-hari siswa, mereka juga merasa bahwa sesi kelompok yang dilakukan masih kurang.

Langkah awal dalam penelitian ini adalah melakukan skrining ketidaksesuaian jurusan dan masalah motivasi yang dialami oleh siswa. Skala motivasi belajar diberikan kepada siswa kelas X dari jurusan Teknik Pemesinan (TP), Teknik Instalasi Tenaga Listrik (TITL), dan Teknik Komputer Jaringan (TKJ). Untuk melihat kategori skor yang diperoleh oleh siswa digunakan data mean hipotetik dengan kategorisasi skala sebagai berikut: 


\section{Tabel 1}

\section{Kategorisasi skor motivasi}

\begin{tabular}{|l|l|l|}
\hline Rumus & $\begin{array}{c}\text { Rentang } \\
\text { Skor }\end{array}$ & Kategorisasi \\
\hline $\begin{array}{l}\mathrm{X} \geq(\mu+ \\
1,0 \mathrm{~s})\end{array}$ & $\leq 52$ & Tinggi \\
\hline $\begin{array}{l}(\mu-1,0 \mathrm{~s}) \\
<\mathrm{X}<(\mu\end{array}$ & $52-$ & Sedang \\
$+1,0 \mathrm{~s})$ & & \\
\hline $\begin{array}{l}1 \mathrm{X} \leq(\mu \\
-1,0 \mathrm{~s})\end{array}$ & $\geq 104$ & Rendah \\
\hline
\end{tabular}

Berdasarkan hasil skrining motivasi belajar yang dilakukan pada siswa, terdapat terjaring 25 siswa yang mengalami ketidaksesuaian pilhan jurusan dengan skor motivasi sedang. Selanjutnya dilakukan FGD untuk melihat permasalahan yang dialami oleh siswa. Dari 25 siswa terdapat 8 siswa yang merasa terganggu dengan permasalahan tersebut dan bersedia untuk diberikan perlakuan berupa konseling kelompok.

Setelah diberikan perlakuan, tahap berikutnya adalah analisis data. Berdasarkan hasil analisis data melalui uji perbandingan paired sample t test diperoleh hasil sebagai berikut:

Tabel 2

Hasil analisis

Paired Samples Correlations

\begin{tabular}{|c|c|c|c|c|}
\hline & & $\mathrm{N}$ & $\begin{array}{c}\text { Correla } \\
\text { tion }\end{array}$ & Sig. \\
\hline $\mathrm{P}$ & pre_tes & \multirow[t]{4}{*}{8} & \multirow[t]{4}{*}{, 712} & \multirow[t]{4}{*}{, 048} \\
\hline ai & $t \&$ & & & \\
\hline $\mathrm{r}$ & post_T & & & \\
\hline 1 & est & & & \\
\hline
\end{tabular}

Hasil analisis menujukkan nilai signifikansi $\mathrm{p}=0.048(\mathrm{p}>0.05)$, yang artinya terdapat perbedaan yang signifikan antara pre-test dan post-test yang dilakukan, dengan nilai korelasi yang diperoleh sebesar 0.712. Berdasarkan hasil diketahui bahwa konseling kelompok efektif untuk meningkatkan motivasi belajar siswa SMK yang mengalami 
ketidaksesuaian minat jurusan. Hasil ini selaras dengan hasil-hasil penelitian sebelumnya (Aulia ${ }^{21}$; Hariyanti \& Muhari ${ }^{22}$; Astuti ${ }^{23}$; Mutammimah ${ }^{24}$; Ningrum \& Wiryosutomo ${ }^{25}$ ).

Sedangkan hasil pengukuran berdasarkan mean hipotetik adalah sebagai berikut:

\section{Tabel 3}

Skor pre-test dan post-test

\begin{tabular}{|c|l|c|c|c|c|}
\hline \multirow{2}{*}{ No } & \multirow{2}{*}{ Subjek } & \multicolumn{2}{|c|}{ Pre-test } & \multicolumn{2}{c|}{ Post-test } \\
\cline { 3 - 6 } & & Skor & Kategori & Skor & Kategori \\
\hline 1. & AR & 65 & Sedang & 70 & Sedang \\
\hline 2. & IS & 71 & Sedang & 84 & Sedang \\
\hline 3. & RA & 69 & Sedang & 78 & Sedang \\
\hline 4. & PS & 68 & Sedang & 68 & Sedang \\
\hline 5. & AK & 81 & Sedang & 81 & Sedang \\
\hline 6. & MS & 79 & Sedang & 80 & Sedang \\
\hline 7. & RT & 74 & Sedang & 79 & Sedang \\
\hline 8. & MA & 79 & Sedang & 85 & Sedang \\
\hline
\end{tabular}

Terdapat peningkatan skor motivasi belajar sebelum dan sesudah diberikan perlakuan. 6 siswa menunjukkan peningkatan skor. Sedangkan 2 siswa tidak menunjukkan adanya perubahan. Adapun grafik perbandingan hasil pre-test dan post-test motivasi dapat dilihat pada gambar berikut:

\footnotetext{
${ }^{21}$ Aulia.

22 Desi Dwi. Muhari Hariyanti, "Aplication of Rational Emotive Behavior Group Counseling to Improve VIII GClass Student Learning Motivation of Yayasan Pendidikan 17 Surabaya Junior High School," Jurnal Pendidikan UNESA 01, no. 01 (2013): 0-206.

${ }^{23}$ N. D. S. Astuti, “Meningkatkan Motivasi Belajar Melalui Layanan Konseling Kelompok," Jurnal Penelitian Tindakan Bimbingan Dan Konseling 1, no. 1 (2015).

${ }^{24}$ Etty Mutammimah, "Peningkatan Motivasi Belajar Melalui Bimbingan Kelompok Dengan Media Audiovisual Pada Siswa Kelas X MAN 1 Kudus," KONSELING EDUKASI "Journal of Guidance and Counseling" 2, no. 1 (2018): 78-97, https://doi.org/10.21043/konseling.v2i1.3932.

${ }^{25}$ H. W. Ningrum, S . ; Wiryosutomo, "Penerapan Konseling Kelompok Realita Untuk Meningkatkan Motivasi Belajar Siswa," n.d., 158-62.
} 


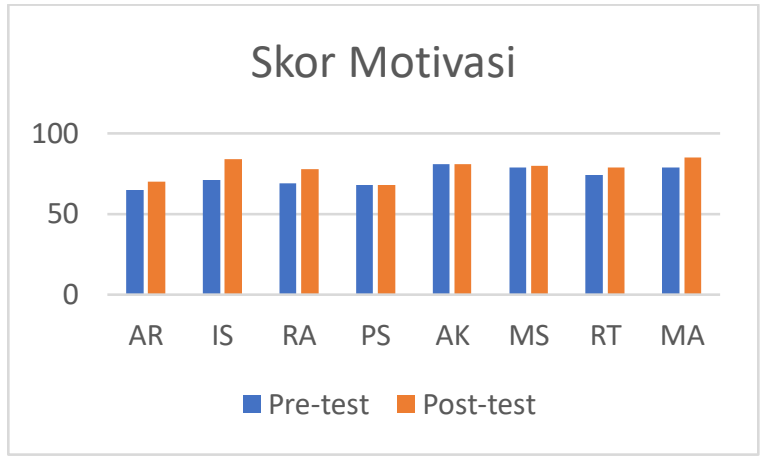

Gambar 1. Grafik pre-test dan post-test

Sebagaimana yang disampaikan oleh Uno (dalam Ningrum \& Wiryosutomo ${ }^{26}$ ) Motivasi ini dapat mendorong kesadaran dan tanggung jawab siswa dalam belajar. Motivasi belajar dapat menjadi pemicu baik dari dalam individu maupun dari luar individu untuk belajar sehingga dapat merubah tingkah laku. Melalui konseling kelompok yang dilakukan, siswa tidak hanya mengenali diri tetapi juga belajar melalui pengalaman teman sebayanya.

Siswa yang mengalami hambatan dalam belajar diajak untuk mengembangkan pribadinya melalui interaksi dengan teman-temannya sehingga mendapatkan insight dan dapat mengatasi permasalahan yang dihadapi $\left(\mathrm{ASCA}^{27}\right)$. Sifat dari proses interaksi dibangun secara dinamis, sehingga dapat membantu siswa dalam memahami perasaan diri dan berhubungan dengan orang lain.

\section{PENUTUP}

Berdasarkan hasil penelitian dan pembahasan diatas, dapat di simpulkan bahwa Konseling kelompok efektif dalam meningkatkan motivasi belajar siswa yang mengalami ketidaksesuaian pilihan jurusan, dengan nilai signifikansi 0,048. Hal ini menunjukkan bahwa terdapat peningkatan skor motivasi sebelum dan sesudah diberikan perlakuan. Adapun saran yang diberikan adalah sebagai berikut:

\footnotetext{
${ }^{26}$ Ningrum, S . ; Wiryosutomo.

${ }^{27}$ American School Counselor Association (ASCA), The School Counselor and Group Counseling, 2014.
} 
1. Konseling kelompok motivasi, bisa juga dilakukan pada siswa lain yang mengalami permasalahan belajar dengan latar belakang yang berbeda-beda, tidak hanya pada siswa yang mengalami ketidaksesuaian minat jurusan.

2. Konseling kelompok motivasi, bisa dijadikan program setiap bulan pada siswa SMK di jurusan-jurusan lain. Sehingga permasalahan belajar yang dihadapi siswa bisa teratasi.

3. Perlu adanya penggalian lebih dalam mengenai faktor lain yang menjadi penyebab permasalahan belajar yang dialami oleh siswa selain ketidak-sesuaian minat jurusan.

\section{DAFTAR RUJUKAN}

American School Counselor Association (ASCA). (2014). The School Counselor and Group Counseling (Adopted 1989; revised 1993, 2002, 2008; reviewed 1999, 2008, 2014). www.schoolcounselor.org

Astuti, N. D. S. (2015). Meningkatkan Motivasi Belajar Melalui Layanan Konseling Kelompok. Jurnal Penelitian Tindakan Bimbingan dan Konseling. Vol. 1, No. 1, Januari 2015. ISSN 2442-9775

Aulia. (2006). Efektivitas Konseling Kelompok Untuk Meningkatkan Motivasi Belajar Siswa Kelas XI IPS Yang Mengalami Ketidaksesuaian Pilihan Dengan Bidang Jurusan (Tesis). Yogyakarta: Universitas Gadjah Mada, Fakultas Psikologi Profesi.

Azwar, Saifuddin. (2010). Pengantar Psikologi Intelligensi: Edisi Kesepuluh. Yogyakarta: Pustaka Pelajar

Cox W. M \& Klinger, E. (2004). Handbook of Motivational Counseling Concepts, Approaches, and Assessment. England: John Wiley \& Sons, Ltd

Crespi, T. D. (2009). Group Counseling in The Schools: Legal, Ethical, And Treatment Issues In School Practice. Journal of Psychology in the Schools, Vol. 46(3), 2009. Published online in Wiley InterScience (www.interscience.wiley.com) DOI: 10.1002/pits.2037. Wiley Periodicals, Inc.

Djamarah, S. B. (2002). Psikologi belajar (Cetakan 1). Jakarta: Rineka Cipta Kamus Besar Bahasa Indonesia (KBBI). (2008). Jakarta: Pusat Bahasa Departemen Pendidikan Nasional.

Hariyanti, D. D \& Muhari. (2013). Penerapan Konseling Kelompok Rational Emotive Behavior Untuk Meningkatkan Motivasi Belajar Siswa Kelas VIII G SMP Yayasan Pendidikan 17 Surabaya. Jurnal BK UNESA. Volume 01 Nomor 01 Tahun 2013, 0 $-216$

Heriyati. (2017). Pengaruh Minat Dan Motivasi Belajar Terhadap Prestasi Belajar Matematika. Jurnal Formatif 7(1): 22-32, 2017. ISSN: 2088-351X

Kamus Besar Bahasa Indonesia (KBBI). (2021). https://kbbi.kemdikbud.go.id 
Kurniawan, D. L, Santoso, D. (2013). Pengaruh Lingkungan Belajar, Minat Belajar Dan Motivasi Belajar Terhadap Prestasi Belajar Siswa Pada Mata Pelajaran Tik Kelas X Sman 1 Kota Mungkid, Magelang. http://eprints.uny.ac.id/10275/1/Jurnal.pdf

Mutammimah, E. (2018). Peningkatan Motivasi Belajar Melalui Bimbingan Kelompok Dengan Media Audiovisual Pada Siswa Kelas X MAN 1 Kudus. Konseling Edukasi: Journal of Guidance and Counseling, Vol 2, No 1 (2018)

Ningrum, S \& Wiryosutomo, H. W. (2020). Penerapan Konseling Kelompok Realita Untuk Meningkatkan Motivasi Belajar Siswa. Jurnal BK UNISMA. Vol 11, No 2

Putri, D. T. N \& Isnani, G. (2015). Pengaruh Minat Dan Motivasi Terhadap Hasil Belajar Pada Mata Pelajaran Pengantar Administrasi Perkantoran. Jurnal Pendidikan Bisnis dan Manajemen, Volume 1, Nomor 2, September 2015

Rahayu, M. (2013). Pengaruh Minat Dan Motivasi Belajar Terhadap Hasil Belajar Siswa Di Smk Ketintang Surabaya. Jurnal Pendidikan Akuntansi Universitas Negeri Surabaya. Vol 1, No 3 (2013)

Ricardo \& Meilani, R. I. (2017). Impak minat dan motivasi belajar terhadap hasil belajar siswa. Jurnal Pendidikan Manajemen Perkantoran, Vol. 2 No. 2, Juli 2017, Hal. 188201

Sari, I. N., Saputri, D. F, Sasmita. (2016). Pengaruh Minat Dan Motivasi Belajar Terhadap Prestasi Belajar Fisika Pada Siswa Kelas XI IPA SMA Negeri 1 Galing Kabupaten Sambas. Jurnal Edukasi Matematika dan Sains. Volume 4, Nomor 2, September 2016, hal 108-114.

Schunk, D. H. (2012). Learning Theories: An Educational Perspective (6 ${ }^{\text {th }}$ Edition). Boston: Pearson Education, Inc., publishing as Allyn \& Bacon, 501 Boylston Street.

Shadish, W. R., Cook, T. D., \& Campbell, D. T. (2002). Experimental and quasiexperimental designs for generalized causal inference. Boston: Houghton Mifflin Co.

Slameto. (2003). Belajar dan Faktor-faktor yang mempengaruhinya. Jakarta: Rineka Cipta.

Syafitri, A. (2004). Gambaran aspek-aspek yang mempengaruhi prestasi belajar pada siswa SMUN 106 Jakarta yang berprestasi akademik rendah. Jurnal psikodinamik 2, $39-57$

Sukada, K.; Sadia, W.; Yudana, M. (2013). Kontribusi Minat Belajar, Motivasi Berprestasi Dan Kecerdasan Logis Matematika Terhadap Hasil Belajar Matematika Siswa Sma Negeri 1 Kintamani. e-Journal Program Pascasarjana Universitas Pendidikan Ganesha Program Studi Administrasi Pendidikan, Volume 4 Tahun 2013 